\title{
КАТЕГОРІЯ ЧАСУ В КІНОПОВІСТІ ОЛЕКСАНДРА ДОВЖЕНКА «ЗАЧАРОВАНА ДЕСНА»
}

\begin{abstract}
У статті здійснено спробу висвітлити сутність основних понять дослідження: «категорія часу», «темпоральність», «лексико-семантичне поле», «ядро поля»; «периферія», «лексико-семантична група», описано мовні засоби відображення часу в кіноповісті Олександра Довженка «Зачарована Десна» на лексичному й граматичному рівнях.

Дослідження виконано в руслі перспективного напряму сучасної лінгвістики - антропоцентричності художнього тексту, згідно з яким концептуалізація світу простежується на прикладі аналізу семантики темпоральності. Установлено, що категорії часу і простору моделюють оповідь, забезпечують сприймання художньої реальності, організовують композицію тексту та формують його зміст.

У статті узагальнено лінгвістичні підходи до витлумачення поняття «темпоральність», яка репрезентує способи сприйняття й усвідомлення часу через систему мовних засобів лексико-граматичного рівня.

На матеріалі кіноповісті здійснено спробу описати часові відношення із застосуванням лексико-семантичного поля «часу», складниками якого є лексико-семантичні групи, серед яких назви неточних часових відрізків; назви приблизних часових проміжків; назви точних часових відрізків; назви пір року; назви частин доби; назви днів тижня, назви періодів життя від отроцтва до зрілого віку. У межах найбільших за обсягом лексико-граматичних груп виділено синонімічні та антонімічні ряди. У ході аналізу з'ясовано, щзо темпоральні номінатори в досліджуваному текстовому матеріалі представлені різними лексико-граматичними розрядами, переважна більшість яких - іменники, прикметники, прислівники, щьо відображають певний фрагмент чи аспект категорії чacy.
\end{abstract}

Ключові слова: художній текст, категорія часу, темпоральність, лексико-семантичне поле, лексико-семантична група, мовні засоби, лексичний рівень, граматичний рівень.

\section{CATEGORY OF TIME IN OLEKSANDR DOVZHENKO'S MOVIE-ESSAY "CHARMED DESNA"}

The essence of the research basic concepts such as "category of time", "temporality", "lexical-semantic field", "field core", "periphery", "lexical-semantic group" are highlighted in the article; linguistic means of displaying time in Oleksandr Dovzhenko's movie-essay "Charmed Desna" are described on the lexical and grammatical levels.

The research is carried out following advanced research direction of modern linguistics - anthropocentrism of the literary text, according to which the conceptualization of the world can be seen on the example of the temporality analysis semantics. It has been determined that the categories of time and space model the narrative, provide the perception of artistic reality, organize the composition of the text and form its content.

The article summarizes the linguistic approaches to the interpretation of temporality which represents ways of perceiving and recognizing time through the system of lexical and grammatical-level language means.

An attempt to describe temporal relations using the lexical-semantic field of «time» has been made based on the movie-essay material; the lexical-semantic groups, which are components of this field, include the names of inaccurate time segments; names of approximate time intervals; names of exact time segments; names of seasons; names of day parts; names of week days; names of life periods from adolescence to maturity. 
Synonymous and antonymous series are identified within the largest lexical and grammatical groups. The analysis revealed that the temporal nominators in the studied text material are represented by different lexical and grammatical categories the great majority of which are nouns, adjectives, adverbs that reflect a certain fragment or aspect of the time category.

Key words: literary text, category of time, temporality, lexical-semantic field, lexical-semantic group, linguistic means, lexical level, grammatical level.

Постановка проблеми. У сучасному мовознавстві спостерігаються докорінні зміни, що виявляються в переорієнтації вивчення мови як незалежної від людини самостійної системи до опису іiі як «антропологічного феномену» (Кубрякова, 1995: 136). Отже, відбувається перехід лінгвістичних досліджень на нову парадигму - антропоцентричну.

Предметом наукових розвідок, здійснених у руслі антропоцентричного підходу, $\epsilon$ взаємозв'язок мови і людини як суб'єкта сприйняття, пізнання і мислення; специфіка сприйняття людиною часу; усвідомлення універсальних i етноспецифічних темпоральних уявлень, відображення їх у мовній картині світу.

Категорії часу і простору виконують важливу роль у створенні художнього тексту, оскільки визначають його жанр, забезпечують композиційну будову, нерозривно пов'язану із сюжетом, системою образів і мотивів (Бахтин, 1975: 235). Проте найважливіша їх роль у тому, що вони виступають формами існування художнього світу.

Аналіз досліджень. Упродовж тривалого періоду - від часів античності до наших днів представники різних наук намагалися 3'ясувати сутність багатоаспектної категорії часу, описати реальність іiі існування в природі і в соціумі, що спричинило формування різних аспектів iï вивчення та виникнення низки таких понять, як біологічний час, психологічний, соціальний, міфологічний, художній.

Здобутки в дослідженні часу окремими науками визначають актуальність проблеми взаємозв'язку реального часу з формами його відображення в тій чи іншій сфері діяльності, в тому числі й у мовній.

У лінгвістиці способи репрезентації часу співвідносяться $з$ поняттям темпоральності, яка усвідомлюється як вираження сприйняття, осмислення й переживання часу. На сучасному етапі ця проблема набула особливої актуальності як у вітчизняних, так і в зарубіжних дослідженнях. Науково значущими в цьому аспекті є розвідки В. Адмоні, О. Бондарка, Т. Матвєєвої, О. Гулиги, М. Гухман та ін., присвячені аналізу функціонально-семантичних часових полів; позначення часових відношень лексичними засобами відображено в роботах Н. Арутюнової, В. Барчука,
С. Романюк, О. Бондаря, О. Кравченко, Г. Павленко, Б. Успенського, К. Яковлєвої, М. Ющенко та ін.; на граматичному рівні часопростір описано в працях А. Бондарка, Ю. Маслова, 3. Тураєвої, М. Поспєлова, О. Нечаєвої, А. Шмельова, В. Жеребкова, Т. Булигіної та ін.; вербалізацію категорії темпоральності синтаксичними засобами дослідили В. Бєлошапкова, М. Всеволодова, Т. Смирнова, І. Вихованець, К. Городенська, О. Безпояско та ін.

Проте, незважаючи на наявність вагомого наукового доробку, питання вербального відображення категорії часу в художніх творах потребує подальшого вивчення, джерельною базою якого може слугувати мовна картина світу О. Довженка. Предметом безпосередньої нашої уваги $є$ кіноповість «Зачарована Десна», багата на яскраві словесно-художні засоби, які забезпечують виразність індивідуального стилю автора.

Мета статті - здійснити функціонально-семантичний аналіз мовних засобів вираження категорії часу в кіноповісті «Зачарована Десна» Олександра Довженка на лексико-граматичному рівні.

Виклад основного матеріалу. Упродовж тривалого періоду проблема часу є предметом різноаспектного вивчення. У філософії вона розглядається як онтологічна категорія, форма існування матерії, яка виражає тривалість буття й послідовність зміни станів усіх матеріальних систем і процесів у світі. Поняття часу, простору й руху розглядаються в тісному взаємозв'язку, причому час визначається як «базова категорія світу», «найважливіший чинник існування світу і людини»(Новейший философский словарь, 2003: 191).

У лінгвістиці час усвідомлюється як антропоцентрична, суб'єктивна категорія. Думка про те, що час співвідноситься 3 поглядом мовця на світ, уперше 3'явилася в теорії лінгвістичної відносності Б. Уорфа, згодом була поглиблена в роботах Ю. Апресяна й Н. Арутюнової, а далі набула широкого розповсюдження в працях відомих вітчизняних і зарубіжних мовознавців.

У функціональній граматиці вивченням часових відношень у мові займалися А. Бондарко, 3. Тураєва, В. Дресслер, М. Всеволодов, І. Гальперін, 3. Тураєв, I. Москальська та ін. Згідно 3 А. Бондарком, темпоральність - це функціо- 
нально-семантична категорія, що виражає сутність фізичного й філософського аспектів часу, які реалізуються різними мовними засобами його вираження: сукупністю граматичних, лексичних комбінованих одиниць, де ядром темпоральності $\epsilon$ граматичний час (Бондарко, 1990).

Загальноприйнятою $є$ думка про те, що категоpiї часу властиві філософський, фізичний і лінгвістичний аспекти. Досліджуючи лінгвістичний аспект часу, Т. Дешерієва ввела поняття лінгвістичного часу, яке визначила як «сукупність способів вираження засобами мови суті фізичного й філософського аспектів цієї категорії» (Дешериева, 1975: 112). Відповідно, темпоральність охоплює лексичний, граматичний (морфологічний i синтаксичний) і контекстуальний час, які $є$ способами вираження сутності фізичного й філософського аспектів означеної категорії лексичними, граматичними і контекстуальними засобами.

Лінгвістичний час як мовна проєкція системи знань людини про цей феномен виражає відношення між реальною дійсністю, діяльністю людини і мовою, бере участь у трансформації об'єктивного світу в суб' єктивний конструкт (картину світу, модель світу), який існує в людській свідомості (Мурьянов, 1978). Засобами його відображення на граматичному й лексичному рівнях $\epsilon$ синтаксичні конструкції, видо-часові форми дісслова, морфеми з темпоральним значенням, темпоральні лексичні одиниці тощо.

Модель темпоральності дослідники порівнюють із незамкненою спіраллю, яка спроектована на мовну площину й охоплює всі рівні мови.

Комплексний аналіз лінгвістичного часу призвів до визначення темпоральності як складної семантичної категорії, яка «відображає сприйняття й осмислення людиною часу позначуваних ситуацій та їх елементів відносно до моменту мовлення» (Бондарко, 1990: 5).

Важливе значення для сучасного потрактування означеної категорії має загальновизнана теорія функціонально-семантичних полів, розроблена відомим вітчизняним мовознавцем О. Бондарком (Бондарко, 1990), а також інші дослідження, присвячені вивченню темпоральності та засобів її вираження в тексті.

Функціонально-семантичне поле в сучасному мовознавстві прийнято розуміти як сукупність переважно лексичних одиниць, об'єднаних спільністю змісту, рідше - спільністю формальних показників, що відображають поняттєву, предметну й функціональну подібність позначуваних явищ (Кочерган, 2000: 211). Аналізуючи лексико-семантичне поле (ЛСП) як парадигмальне об'єднання лексичних одиниць певної частини мови за спільністю інтегрального компонента, О. Селівнова виділяє такі його структурні компоненти: центр, тобто найуживаніші слова 3 яскравим інтегральним значенням, та периферію слова, яким властива менша частотність уживання й послаблене стилістичне забарвлення значення (Селіванова, 2006: 282).

Кожне поле у своїй структурі має спільну (інтегральну) ознаку, яка об'єднує всі одиниці поля, тобто архісему, виражену лексемою з узагальненим значенням. Усі інші одиниці лексикосемантичного поля відрізняються одна від одної принаймні однією диференційною ознакою (Кочерган, 2000: 211).

Лексико-семантичне поле має ієрархічну структуру. Воно складається з лексико-семантичних груп, тобто множини різноструктурних одиниць, сформованих на основі спільності семантичного ядра, що зумовлює взаємозалежність і взаємовідношення елементів групи як одиниць мовної системи (Крехно, 2005). У межах лексикосемантичних груп виділяють мінімальні семантичні об'єднання, побудовані на відношеннях синонімії, антонімії, конверсії та гіпонімії тощо.

Розглянемо вербалізацію категорії часу засобами лексико-граматичного рівня на матеріалі кіноповісті Олександра Довженка «Зачарована Десна». Найбільш доцільним, на нашу думку, $є$ аналіз темпоральної лексики в мовній картині світу О. Довженка на матеріалі лексико-семантичного поля.

У результаті проведеного дослідження в структурі лексико-семантичного поля темпоральності (часу) були виокремлені лексико-семантичні групи (далі - ЛСГ), які далі аналізувалися за лексичними і морфологічними особливостями: назви неточних часових відрізків; назви приблизних часових відрізків; назви точних часових відрізків; назви пір року; назви частин доби; назви місяців; назви днів тижня.

Найбільшою за обсягом у кіноповісті є ЛСГ «Назви неточних часових відрізків», представлена групою лексем, які вказують на те, що дія відбувалася в певну епоху, час, пору, період. Серед виписаних номінацій простежуються такі, що позначають як найдовші за часовим виміром відрізки, так і найкоротші, зокрема: час, вічність, епоха, ера, вік, пора, момент, період, момент, мить. Наприклад: ... я роблю ту лише «помилку», яку роблять і робитимуть, скільки й світ стоятиме, душі народні живі всіх епох $i$ народів, згадуючи про незабутні чари дитинства (Довженко, 2007: 198); Вони не знали, як змінити його, $i$, від- 
даючи перевагу тому, чого не судила їм доба, не порадувались... (Довженко, 2007: 199); В самий найвирішальніший момент раптом виявилась відсутність курка (Довженко, 2007: 189); Вони справді виспівали всі свої пісні за маленький свій вік, ніби віщуючи коротку свою мить (Довженко, 2007: 199);

Домінантною в тексті $\epsilon$ лексема «час», яка в контекстуальному оточенні інших іменників, прикметників чи дієслів набуває різних характеристик, зокрема: постійна плинність, безперервність: ...він, усміхаючись, докірливо хитав головою і промовляв з почуттям тонкого жалю $і$ примиренності з бігом часу (Довженко, 2007: 153); відсутність чітких меж: Тільки було це так давно, щуо майже все вже розтануло в далекім мареві часу, як сон, $i$ потонуло (Довженко, 2007: 199); альтернативність і ймовірність: ...i всі наші пригоди і вчинки течуть, як вода, між берегами часу (Довженко: 198); початок відліку: Від того часу я ні разу не вдарив коня (Довженко, 2007: 195); неосяжність, вічність: I вони тоді довго і повільно, ніби линучи в безмежнну далечінь часу, на сімсот, може, літ, виспівують мені талан (Довженко, 2007: 195).

Семантичний обсяг лексеми «час» у Довженка представлений такими лексико-семантичними варіантами: скрутний період: Що призвело тебе до иьього в такий великий час - біль, страх? (Довженко, 2007: 198); епоха, окремий етап у житті народу: Я син свого часу $і$ весь належу сучасникам своїм (Довженко: 198); смертна година: Так під сонцем на погребні, коло яблуні, він i помер, коли прийшов його час (Довженко: 153); певний період, що стосується пори року: Зате багато дачників тепер купається в трусах, на зло робочим людям, в гарячий літній час (Довженко: 199); відрізок часу, який передував безпосередньо такому самому відрізку, моменту або настане після нього: Весь в полоні у сумного i весь в той же час з якоюсь внутрішньою високою культурою думок $i$ почуттів (Довженко: 168); пора, коли щось триває, відбувається: Під час бою він весь палав (Довженко: 183); відрізок часу в 60 хвилин: Топив наш батько кораблі задля того, щуоб бодай хоч іноді у брудному шинку маленька калюжа його життя обернулась хоч на час у море (Довженко: 176) та ін.

Варто зазначити, шо саме в цій лексикосемантичній групі можна спостерігати елементи, пов'язані між собою відношеннями смислової подібності чи смислового протиставлення. Так, синонімічні ряди утворюють лексеми на позначення:
- давноминулих часів (старовина, давнина, 3 давніх-давен; старі часи, нетрі старовини, далечінь часу): Було се в далекі старі часи, коли ми не мали щзе здорового розуму (Довженко: 198); Tут дід заводив нас у такі казкові нетрі старовини, щзо ми переставали дихати й бити комарів на жижках і на шиї (Довженко: 153);

- тривалості існування, що вимірюється роками (роки, літа): Щасливий я, щуо народився на твоєму березі, щуо пив у незабутні роки твою м'яку, веселу, сиву воду (Довженко: 200); Десно, щзо, згадуючи тебе вже много літ, я завжди добрімав, почував себе невичерпно багатим $i$ щзедрим (Довженко: 200);

- осіб, які жили або живуть в один час, в одну епоху з ким-, чим-небудь (син свого часу, сучасник): Я син свого часу $і$ весь належу сучасникам своїм (Довженко: 198);

- тривалості життя людини (ціле жсиття, свій вік тощо): Таж, певно, не знайшли одне одного чи не доглянули, $і$ гнів, і ненависть, які були огидні їм ціле жсиття, підкинула їм ворожка-чарівниця (Довженко: 199); Всі прожили свій вік нещуасливо, кожен по-своєму - $i$ прадід, і дід, і батько $з$ матір 'ю (Довженко: 199).

Деякі елементи лексико-семантичної групи вступають в антонімічні відношення, як-от: будні - свята; епоха - мить та ін. Наприклад: Я вертаюсь з Дунаю до хати, оглядаюсь: аж $i$ мати співає, гойдаючи колиску, і в неї зовсім не хатня мрія, щуось зовсім не буденне, ніби сама вона теж лине десь у просторах свого серия (Довженко: 196); Вірили в свята (Довженко: 156).

Наступна лексико-семантична група «Назви приблизних часових проміжків» представлена іменниками часової семантики в поєднанні з числівниками, прислівниками, прийменниками, які вказують на приблизність: коло ста ліm, років через десять чи двадцять, років 3 півтораста, много літ, днів два або три, не один десяток років. Наприклад: Він прожив під сонцем коло ста літ, ніколи не ховаючись у холодок (Довженко: 153); 3 того часу, шиось років через десять чи двадиять, мати об'явила себе ворожкою і почала лікувати людей від зубів, пристріту й переляку, хоч і сама хворіла (Довженко: 160); Погодою у нас на сінокосі щуось, казали, років з півтораста завідувала ворона (Довженко: 187).

Самостійною семантичною групою $є$ «Назви днів тижня». У кіноповісті вона представлена найбільш частотними лексемами неділя, субота, середа: Отак почавши розговлятись у суботу, потрошки-помаленькупоснулими(Довженко: 175); У неділю перед богами горіла маленька синенька 
лампадка (Довженко: 152); Він був письменний по-церковному і в неділю любив урочисто читати псалтир (Довженко: 152); «Воскресенія день просвітимось, людіє!» (Довженко: 177). Цілком закономірно, що в тексті домінують лексеми неділя, субота, оскільки для християн це були дні, які асоціювалися 3 радісною подією Христового Воскресіння і були призначені для відпочинку від тяжкої праці, для поклоніння Богу.

У кіноповісті виокремлено також семантичну групу «Назви подій», пов'язаних зі святами, переважно релігійними: святе різдво, свята паска, хрещення, великдень, спас, піст, зелена неділя, Христове воскресіння, наприклад: Удосвіта Христове воскресіння (Довженко: 175); Сталося це, кажуть, якраз на зелену неділю (Довженко: 167); Справді, чого мені хвалити бога, і особливо на великдень, от за таку повідь? (Довженко: 178); Доспіли груші й яблука на сnаса. Малина й вишні одійшли давно (Довженко: 197); Я - зирк у вікно: то не повний місяць з зоряного неба усвітив у хату перед Новим роком (Довженко: 195); із старовинними обрядами: колядки, щедрівки, веснянки, обжинки, косовиця: Любив співи дівочі, колядки, щеерівки, веснянки, обжинки (Довженко: 165); іншими періодами в житті: чумацтво, посів, сінокіс, косовиця, служба божа, вечірня: Після косовиці починаєм гребти сіно гуртом.. (Довженко: 182); Отак почавши розговлятись у суботу, потрошкипомаленьку поснули ми, проспали службу божу (Довженко: 175); Приємно, коли позіхає дід, і коли дзвонять до вечерні літом (Довженко: 164).

Окремо виділено в «Зачарованій Десні» ЛСГ «Назви періодів життя людини від отроцтва до зрілого віку» і семантично близьких із ними іменників: дитинство, юність, старість; хлопчик, дівка, старий, діб, баба, предок, батько, предок, наприклад: Сумно і смутно людині, коли висихає $i$ сліпне уява, коли, обертаючись до найдорожчих джерел дитинства та юнацтва, нічого не бачить вона дорогого, небуденного... (Довженко: 190); Була тоді ще діккою Десна, а я-здивованим маленьким хлопчиком із широко розкритими зеленими очима (Довженко: 201); Крім того, дідовому покійному батькові Тарасу колись давно, ще за старих часів, змій носив уночі гроші в трубу (Довженко: 159).

В окрему групу об'єднуємо лексеми на позначення частини дня: полудень, обід, вечір, день, ранок. Наприклад: Аж ось в неділю, тижнів через n'ять, якраз після обіду, коли ми сиділи всі коло хати, лузаючи насіння, дивимось - біжсть Пірат, заморений, худючий (Довженко: 192); Який там полудень! Вечеряти вже пора (Довженко: 184); Здається, не плив я човником тієї ночі по Десні (Довженко: 191).

Засоби репрезентації пронизують у морфологічний рівень твору. О. Довженко відтворив темпоральну картину кіноповісті за допомогою різних лексико-граматичних категорій.

Найбільшою за обсягом $є$ ЛСГ прислівників, які позначають різні часткові темпоральні значення вияву процесуальних і непроцесуальних ознак, а саме:

1) співвідносність дій у часі з указівкою на порядок перебігу дій (спершу, спочатку, вперше, раніше, перед тим, потім, після того, згодом, пізніше): От тоді-то вперше в житті $і$ вирішив я творити добрі діла (Довженко: 161); Хай потім понесуть мене до ями, а я коло ями як оживу, та чого коло ями, я ще раніме оживу (Довженко: 157); Але трохи згодом материні діла похитнулись (Довженко: 160); Спочатку вона довго лежала в сінях під ступою (Довженко: 162);

2) співвіднесенність дії з теперішнім часом (сьогодні, зараз, тепер, нині, якраз): Нi, дядьку, сьогодні не вийде (Довженко: 189); Кішка виводила в ній кошенят, а зараз кошенят баба потопила в копанці й шапку викинула в човен (Довженко: 162); ...вже ніхто тепер ї̈ не буде ні дратувати, ні докоряти довгим життям (Довженко: 170);

є) позначення часу в межах доби (вранці, зранку, ввечері, вночі, вдень): I хоч Тихон категорично відмовився стріляти не дозволену законом божим птиию, вона повернулася з дуба тільки ввечері (Довженко: 188); Там було темно навіть удень, $і$ ми боялись гадюки (Довженко: 151); Високе полум'я палахкотіло вночі, тріщало (Довженко: 179).

ЛСГ прикметників 3 темпоральною семантикою містить лексеми, що позначають: 1) постійну тривалість дії (вічний, довічний, постійний та ін.): Якась тайна, і сум, і вічна неухильність закону почувалися завжди в цьому падінні плода (Довженко: 165); Дивно й жалісно часом думати, що нема в нас сили $і$ ясності духу пройнятися щоденним розумінням щастя життя, мінливого в постійній драмі ци радості (Довженко: 180); 2) співвідношення темпоральної ознаки з моментом мовлення (минуле, сучасне, майбутне): Сучасне завжди на дорозі з минулого в майбутне (Довженко: 199); Коли ж обертаюсь я часом до криниці, з якої пив колись воду, і до моєї білої привітної хатини і посилаю їм у далеке минуле своє благословення (Довженко: 198); 3 ) ознаку у відношенні до пори року (зимовий, літній, весняний): ...вже хто знав, чи то від морозу, чи такі дівчата 
і слова колядки у зимовий вечір, тільки спів лунає так дзвінко і гучно (Довженко: 195); Зате багато дачників тепер купається в трусах, на зло робочим людям, в гарячий літній час (Довженко: 199) та ін.

Важливу роль у вираженні темпоральних відношень виконують дісслівні форми теперішнього, минулого i майбутнього часу, які в художньому тексті служать потужним засобом відтворення динаміки життя, подій, станів. Грамемам минулого часу в аналізованому творі відведено найбільше місця, оскільки повість «Зачарована Десна»є спогадом автора про далекі щасливі роки дитинства в рідному селі, про батьків, про простих українських людей, їхні звичаї, традиції. Тому переважну кількість становлять саме дієслова минулого часу, які називають об'єктивно реальні дії, процеси та стани, що відбувалися або відбулися в певний часовий проміжок до моменту мовлення (схоплювався, клекотів, довіряли), наприклад: Кіика виводила в ній кошенят, а зараз кошенят баба потопила в копанцуі й шапку викинула в човен (Довженко: 162); Коли вони померли від пошесті зразу всі в один день, люди казали: «Ото господь забрав $\ddot{x}$ до свого ангельського хору» (Довженко: 167).

У часовій парадигмі темпоральних дієслів заслуговують на увагу виразні й повноцінні 3 функціонального погляду форми давноминулого часу, в яких допоміжне дієслово виступає як формант, за допомогою якого одна 3 двох минулих дій позначається як попередня, передминула: Koma вона проклинала щуодня по два-три рази так, щуо він трохи згодом був якось захворів $i$ здох десь у тютюні (Довженко: 156).

Стилістичної виразності розповіді надають комбінації дієслівних зв'язок, виражених формою минулого часу в поєднанні $з$ дієсловами теперішнього або майбутнього часу (підемо було, іде було, як було зацвіте та ін.), наприклад: А сад було як зацвіте весною! (Довженко: 151).

Дієслова теперішнього часу в тексті позначають: 1) дію, що збігається 3 моментом мовлення про неї, не обмежену часовими рамками: $I$ ось відчиняться ворота, мати хреститься $i$ щзось проказує, коні рушають - ми їемо (Довженко: $181)$; 2) дію, що є властивістю істоти або предмета: ...а чумаки не любили заліза, бо воно, казали, притягає грім (Довженко: 182); 3) дію тривалу або постійну: $A$ щзо робилось на початку літа - огірки цвітуть, гарбузи цвітуть, картопля цвіте (Довженко: 151). Дієслова постійного теперішнього часу означають дії, процеси і стани, що відбуваються в момент мовлення, а також в усі періоди часу й після моменту мовлення.
Грамеми майбутнього часу в тексті виражають процесуальні ознаки, що реалізуються як дії або стани, які настають після моменту мовлення. Такі дієслова мають прості (заголосить, принесемо, підвернеться), складні (робитимуть, стоятиме, поспінатимуть, викидатиме) i складені (будеш робити, будуть ховати) форми вираження, наприклад: Oй будеш же тепер ти, Одарочко, робити моїм іменем людям добро... (Довженко: 159); - Ой як же не зарегоче наме потоплене село, як не возрадуються стріхи! (Довженко: 266). Як бачимо, форми майбутнього часу можуть виражати тривалу, необмежену в часі дію (битимеш, хреститиме, стоятиме) й одноразову, обмежену дію з вказівкою на іï завершеність (продиктує, понесе тощо). Експресивнооцінними в повісті є форми дієслів майбутнього часу на позначення минулих дій, в яких йдеться про раптовість чи повторюваність певних процесів: Чого тільки не насадить наша невгамовна мати (Довженко: 151).

Стилістично виразними у творі $є$ речення, в яких комбінуються синтетичні й аналітичні форми майбутнього часу: Довго-довго, не один десяток років буде проводжати мене мати, дивлячись крізь сльози на дорогу, довго хреститиме мені слід і стоятиме з молитвами на зорях вечірніх і ранішніх, щзоб не взяла мене ні куля, ні шабля, ні наклеп лихий (Довженко: 181). Емоційними $є$ також речення, насичені однотипними формами майбутнього часу, які, з одного боку, створюють перед читачем образ майбутньої дії, а 3 іншого увиразнюють текст, привертаючи увагу мовця до оповіді: Хай потім понесуть мене до ями, а я коло ями як оживу, та чого коло ями, я ще раніше оживу, та як схоплюсь, а баба як побіжить куди-небудь і не вернеться (Довженко: 157).

Функцію експресивно-емоційної оцінки виконують дієслівні форми на позначення раптовості, інтенсивності, миттєвості процесів, дій, станів: А човен тоді хить на другий бік, - од дяка й паламаря тільки жмурки пішли (Довженко: 158); Я зирк у вікно: то не повний місяџь із зоряного неба усвітив у хату перед Новим роком (Довженко: 195). Отже, кинувиись через тютюн y сад, прабаба бухнулась з розгону на коліна (Довженко: 156).

Висновки. Отже, як показали результати проведеного дослідження, темпоральна система кіноповісті О. Довженка «Зачарована Десна» вибудована у вигляді великого лексико-семантичного поля, в якому його всі елементи об'єднані спільною архісемою «час» у різноманітні лексико-граматичні групи. Часові відношення у творі пред- 
ставлені на зіставленні або протиставленні осей минулого - сьогодення - майбутнього. Мовні засоби, відібрані автором відповідно до тієї чи іншої дії, ситуації, характеризують іiї в різних аспектах: тривалість, моментальність, швидкоплинність, повторюваність, одиничність, митте- вість, вічність, циклічність, незворотність. Для опису часових відношень у тексті використано темпоральні номінатори різних тематичних груп, переважна більшість яких - іменники, дієслова, прислівники, рідше прикметники, що відображають певний фрагмент чи аспект реальної дійсності.

\section{СПИСОК ВИКОРИСТАНИХ ДЖЕРЕЛ}

1. Бахтин М. М. Формы времени и хронотопа в романе. Очерки по исторической поэтике. Вопросы литературы и эстетики. Москва : Художественная литература, 1975. С. 234-407.

2. Бондарко А. В. Теория функциональной грамматики: Темпоральность. Модальность. Ленинград : Наука, 1990. $264 \mathrm{c}$.

3. Дешериева Т. И. Лингвистический аспект категории времени в его отношении к физическому и философскому аспектам. Вопросы языкознания. 1975. № 2. С. 111-117.

4. Довженко О. П. Зачарована Десна. Кіноповісті, оповідання, щоденник. Харків : Фоліо, 2007. 287 с.

5. Кочерган М. П. Вступ до мовознавства : підручник для студентів філологічних спеціальностей вищих закладів освіти. Київ : Видавничий центр «Академія», 2000. 368 с.

6. Крехно Т. І. Історія ЛСГ «плати - податки - повинності» в українській мові XV-XVIII ст. (на матеріалах українських пам’яток) : автореф. дис. ... на здобуття наук. ступеня канд. філол. наук : 10.02 .01 «Українська мова». Харків, 2005. $19 \mathrm{c}$.

7. Кубрякова Е. С. Эволюция лингвистических идей во второй половине XX века (опыт парадигмального анализа). Язык и наука конца ХХ века. Москва : Изд-во РГГУ, 1995. С. 144-238.

8. Мурьянов М. Ф. Время (понятие и слово). Вопросы языкознания. 1978. № 2. С. 52-66.

9. Новейший философский словарь. 3-е изд., исправл. Минск : Книжный Дом, 2003. 1280 с.

10. Селіванова О. О. Сучасна лінгвістика : термінологічна енциклопедія. Полтава : Довкілля. Київ, 2006. 716 с.

\section{REFERENCES}

1. Baxtin M. M. Formy vremeni i xronotopa v romane. Ocherky po istoricheskoj poetike. [Forms of time and chronotope in the novel. Essays on historical poetics] Issues on Literature and Aesthetics. M.: Fictional Literature Publishing, 1975, pp. 234-407 [in Russian].

2. Bondarko A. V. Teoriya funkcyonalnoj grammatyky': Temporal'nost'. Modal'nost' [Functional Grammar Theory: Temporality. Modality]. L. : Science, 1990. 264 p. [in Russsian].

3. Desheriyeva T. I. Lingvisticheskyj aspekt kategorii vremeni v ego otnoshenii k fizicheskomu i filosofskomu aspektam. [The linguistic aspect of time category in its relation to the physical and philosophical aspects] Linguistics Issues. 1975. № 2. pp. 111-117 [in Russian].

4. Dovzhenko O. P. Zacharovana Desna. Kinopovisti, opovidannya, shhodenny`k [Charmed Desna. Film-essays, stories, diary]. Kharkiv : Folio, 2007. 287 p. [in Ukrainian].

5. Kocherhan M. P. Vstup do movoznavstva : Pidruchnyk dlya studentiv filolohichnykh spetsial'nostey vyshchykh zakladiv osvity [Introduction to Linguistics: A textbook for students of philological specialties of higher education establishments] K. Publishing Center «Academy», 2000. 368 p. [in Ukrainian].

6. Krekhno T. I. Istoriya LSP «platy - podatky - povynnosti» v ukrayins'kiy movi XV-XVIII (na materialakh ukrayins'kykh pam"yatok) [History of LSG «fees - taxes - duties» in the Ukrainian language of the XV-XVIII centuries (based on the materials of Ukrainian landmarks)] : abstract for science degree of Cand. Philol. Science. Kharkiv, 2005. 19 p. [in Ukrainian].

7. Kubryakova Ye. S. Evolyutsiya lingvisticheskikh idey vo vtoroy polovine XX veka (opyt paradigmal'nogo analiza) [Evolution of linguistic ideas in the second half of the XX century (experience of paradigmatic analysis)]. Language and science of the late twentieth century. M. : Publishing house of the Russian State Humanitarian University, 1995. pp. 144-238 [in Russian].

8. Mur'yanov M. F. Vremya (ponyatiye i slovo). [Time (the concept and the word).] Linguistics Issues. 1978. № 2. pp. 52-66 [in Russian].

9. Noveyshiy filosofskiy slovar'. 3-ye izd., ispravl. [The newest philosophical dictionary. 3rd ed., Revised]. Minsk : Book House, 2003. 1280 p. [in Russian].

10. Selivanova O. O. Suchasna linhvistyka : terminolohichna entsyklopediya [Modern linguistics: terminological encyclopedia]. Poltava: Environment. 2006. 716 p. [in Ukrainian]. 